\title{
Stand Dynamics of Dipterocarp Trees in Cambodia's Evergreen Forest and Management Implications \\ -A Case Study in Sandan District, Kampong Thom*1-
}

\author{
Nophea Kim Phat*2, Syphan Ouk*3, Yuji Uozumi*4 and Tatsuhito Ueki*4
}

\begin{abstract}
ABSTRAC'T
The purpose of this study was to explore the stand dynamics of dipterocarp species in evergreen forest as a basis for devising suitable management systems for Cambodia's forests. The data for this study were obtained from a two -year UNDP-funded forest inventory project in Sandan district of Kampong Thom province. A sample of 18 clusters located in evergreen forest were analyzed. Based on the average stand volume per hectare, this evergreen forest was further divided into poor (less than $200 \mathrm{~m}^{3}$ ), medium $\left(200-300 \mathrm{~m}^{3}\right.$ ) and rich (greater than $300 \mathrm{~m}^{3}$ ). forests. Dipterocarps contributed $50 \mathrm{~m}^{3}(36 \%), 109 \mathrm{~m}^{3}(43 \%)$ and $163 \mathrm{~m}^{3}(53 \%)$ in poor, medium and rich forests, respectively. The dominant dipterocarps species were CHBG (Dipterocarpus turbinatus), CRMS (Vatica astrotricha) and PHDK (Anisoptera glabra).

To estimate the forest potential and allowable cut of dipterocarps stands, trees of DBH greater than $45 \mathrm{~cm}$ were analyzed. Cambodia's silvicultural treatment prescribes that only $30 \%$ of stands are extracted on a selective felling cycle of 25-30 years. On the basis of this silvicultural treatment and management experience in Southeast Asia, the harvest potential of Cambodia's forest was estimated to vary from $20 \mathrm{~m}^{3} /$ ha (6 trees) to $54 \mathrm{~m}^{3} / \mathrm{ha}$ ( 13 trees); approximately $65 \%$ of which was dipterocarps. These figures are more than double the current harvest rate of 10 $\mathrm{m}^{3} /$ ha. However, applying such a new management system might cause forest degradation if there is no long-term political commitment to management and research from the government and parties involved. Permanent and regular research on stand dynamics and other influential factors are required to ensure the sustainability of forest resources. Forest management can no longer be concerned solely with timber production; thus, harvesting and research in non-timber forest products should also be included in the management plan.
\end{abstract}

Keyword: Cambodia, dipterocarps, evergreen forest, forest management

\section{INTRODUCTION}

${ }^{* 1}$ A part of this paper was presented at the $48^{\text {th }}$ Branch Meeting of Japanese Forestry Society, Fukui (1999)

${ }^{* 2}$ Doctoral Program in Agricultural Science, United Graduate School of Agricultural Science, Gifu University / Laboratory of Forest Planning in Shinshu University. 8304 Minamiminowa, Kamiina, Nagano 399-4598.

${ }^{* 3}$ Department of Forestry and Wildlife, Phnom Penh, Cambodia.

${ }^{* 4}$ Faculty of Agricultural Science, Shinshu University, 8304 Minamiminowa, Kamiina, Nagano 399-4598
Tropical forests occupy only $7 \%$ of the Earth's land area, but they contain the majority (approximately 50-90\%) of the Earth's species (WorLd Resources InstiTute, 1989). Many functions of a tropical forest can be best met by careful natural forest management which is able to produce wood and other products with low inputs, provide a livelihood for people living in the forest and preserve ecological functions to a high degree (Weidelt, 1996). Unfortunately, as a result of rapid development and fast growing population, the sustainability of tropical forests has been problematic in recent years. Although several 
attempts have been made to bring the forests under sustainable use and management, sustainability still remains dependent on the search for balance between the needs of present and future generations. Lack of knowledge of stand dynamics of different forest types might be one of the causes of mismanagement; hence the un-sustainability of use of the world's tropical forests today. Dipterocarps are dominant in tropical forests, and commercially important. Dipterocarp forests of Southeast Asia constitute a major and particularly valuable component of the world's tropical rain forests. The bulk of tropical timber comes from Dipterocarp ecosystems (CHOONG and Achmadi, 1996).

Over the past 30 years of political instability, Cambodia's forests were left unmanaged and since then no forestry research has been done to improve the current forest management systems. Therefore, this study's purpose was to explore the stand dynamics of evergreen forest,

Table 1 Recording procedure in each sample plot

\begin{tabular}{ccc}
\hline $\begin{array}{c}\text { Dimension of sample plots } \\
(\mathrm{m})\end{array}$ & $\begin{array}{c}\text { Area } \\
(\mathrm{ha})\end{array}$ & $\begin{array}{c}\text { DBH Classes } \\
(\mathrm{cm})\end{array}$ \\
\hline $10 \times 10$ & 0.01 & $5-9.9$ \\
$20 \times 20$ & 0.04 & $10-29.9$ \\
$60 \times 20$ & 0.12 & $>30$ \\
\hline
\end{tabular}

focussing mainly on dipterocarp stands as a basis for devising suitable management systems for Cambodia's forests.

\section{STUDY METHODS}

Forest inventory

With the financial assistance of UNDP (United Nations Development Program), an executive agency of FAO, and a counterpart of the Department of Forestry and Wildlife, a two-year forest inventory project was initiated in 1995 and started operationally in January 1996. This inventory project covered 0.5 million ha of forests in Cambodia's two largest districts, Sandan and Santuk of Kampong Thom province.

Under this two-year inventory project, cluster sampling was chosen for practical reasons (DFW, 1998a). The clusters were set on $4 \times 4-\mathrm{km}$ grid lines (Fig. 2). Approximately 131 clusters were identified on the map for sampling; however, due to security and other reasons, only 66 clusters were successfully measured, of which 23 were located in evergreen, 36 in mixed, and 4 in deciduous forest, respectively. Only 18 of the 23 clusters in evergreen forest were analyzed. Each cluster contains 9 plots of $20 \times 60 \mathrm{~m}$ size; three plots in a line at equidistant intervals of

Table 2 Tree Species of Dipterocarpaceae family in Cambodian forests

\begin{tabular}{llll}
\hline \multicolumn{1}{c}{ Scientific name } & \multicolumn{1}{c}{ Local name } & Species code & Commercial group \\
\hline Anisoptera glabra & Phdeak & PHDK & Keruing \\
Dipterocarpus costatus & Chhieutiel Neandeng & CHND & Keruing \\
Dipterocarpus tuberculatus & Khlong & KHLG & Keruing \\
Dipterocarpus intricatus & Trac & TRAC & Keruing \\
Dipterocarpus alatus & Chhieutiel Tiek & CHTK & Keruing \\
Dipterocarpus dyeri & Chhieutiel Chgor & CHCG & Keruing \\
Dipterocarpus turbinatus & Chhieutiel Beng & CHBG & Keruing \\
Dipterocarpus obtusifolius & Tbeng & TBEG & Merawan \\
Hopea recopi & Chramas Tiek & CHMT & Merawan \\
Hopea ferrea & Korki Thmor & KKTM & Merawan \\
Hopea pierrei & Korki Ksach & KKKS & Merawan \\
Hopea odorata & Korki Masao & KKMS & Merawan \\
Hopea helferi & Korki Deck & KKDE & Resak \\
Vatica astrotricha & Chramas & CRMS & Resak \\
Vatica philastreana & Tralat & TRLT & Resak \\
Vatica odorata & Chramas Tmor & CRTM & Meranti \\
Shorea thorelli & Pchek Udom & PCUD & Meranti \\
Shorea siamensis & Ring Phnum & RIPM & Meranti \\
Shorea hypochra & Korki Pnorng & KKPN & Meranti \\
Shorea farinosa & Lumbior & LMBI & Meranti \\
Shorea obtusa & Pchek & PCEK & Meranti \\
Shorea vulgaris & Chor Chong & PPEL & \\
Shorea cochinchinnensis & Po Peil & &
\end{tabular}


$100 \mathrm{~m}$ with $100 \mathrm{~m}$ between the lines which are oriented to the north. All trees within DBH classes of 5-10, 10-30 and greater than $30 \mathrm{~cm}$ were recorded in $0.01 \mathrm{ha}, 0.04 \mathrm{ha}$ and 0.12 ha sample plots, respectively (Table 1 ).

Data analysis

The data for this study were made available by FAO's representative in Cambodia, with the approval of DFW.

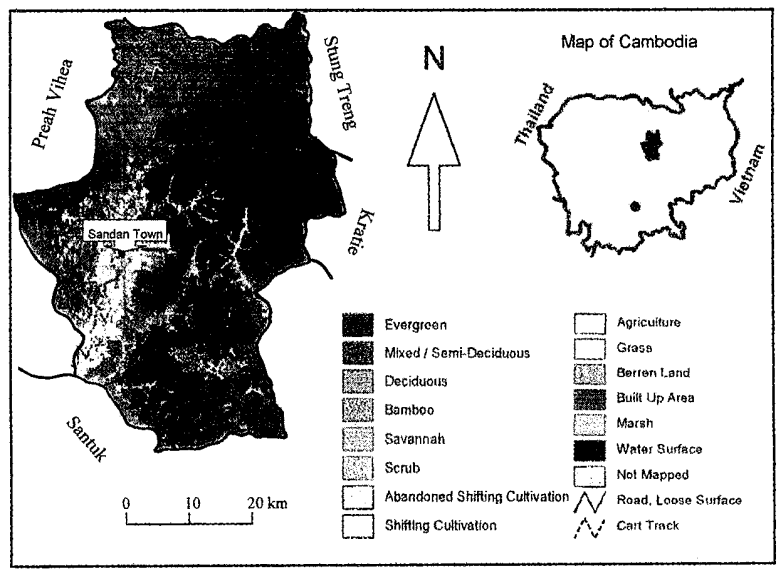

Fig. 1 Forest and land cover map of Sandan Note: This map was prepared by DWF in 1997
As agreed in discussion with DFW, analysis based on a single cluster is not considered adequate to represent the whole forest. Thus, the authors analyzed data in 18 clusters, and took the average result of each plot by grouping into dipterocarps, non-dipterocarp, and unknown trees in order of diameter class of 5-9, 10-19, 20-29, 30-39, 40-44, $45-49,50-59,60-69$, and greater than $70 \mathrm{~cm}$. To estimate the harvest potential, the authors split the diameter class of $40-49 \mathrm{~cm}$ into $40-45 \mathrm{~cm}$ and $45-49 \mathrm{~cm}$ due to the fact that the diameter limit for harvest of some trees is set at $45 \mathrm{~cm}$ DBH. Dipterocarp trees were further classified into their genera and species for the stand dynamics study. In addition to these data, fieldwork was carried out between April and May 1999 to check some of the sampled clusters.

\section{LITERATURE REVIEW OF DIPTEROCARPS}

Dipterocarp trees generally are very dominant in the tropical forests and are now the major source of timber in Southeast Asia (CHOONG and Achmad, 1996). All dipterocarpaceae species are arborescent and tropical. The family type genus is the Asian Dipterocarpus Gaertn $\mathrm{f}$. Dipterocarps are trees with alternate entire leaves and pentamerous flowers. The family Dipterocarpaceae sensu stricto is homogeneous and limited to Asia, while the Dipterocarpaceae sensu lato include three subfamilies: Dipterocarpoideae in Asia, Pakaraimoideae in South America; and Monotoideae in Africa and South America

Table 3 Changes in land use in Sandan district

\begin{tabular}{lrrrrrr}
\hline \multicolumn{1}{c}{ Type of land } & \multicolumn{2}{c}{ Area (1992-'93) } & \multicolumn{2}{c}{ Area (1996-'97) } & \multicolumn{2}{c}{ Change } \\
\cline { 2 - 6 } \multicolumn{1}{c}{ Forest area } & \multicolumn{1}{c}{ (ha) } & \multicolumn{1}{c}{$(\%)$} & \multicolumn{1}{c}{ (ha) } & (\%) & (ha) & $(\%)$ \\
\hline Evergreen dense & 261,974 & 89.9 & 260,798 & 89.5 & $-1,176$ & -0.4 \\
Evergreen disturbed & 41,516 & 14.2 & 41,516 & 14.2 & 0 & 0.0 \\
Evergreen mosaic & 174,922 & 60.0 & 173,177 & 59.4 & 1,745 & -0.6 \\
Mixed dense & 5,986 & 2.0 & 6,775 & 2.3 & 789 & 0.3 \\
Mixed disturbed & 732 & 0.2 & 732 & 0.2 & 0 & 0.0 \\
Mixed mosaic & 7,332 & 2.5 & 7,287 & 2.5 & -45 & -0.0 \\
Deciduous & 3,597 & 1.2 & 3,597 & 1.2 & 0 & 0.0 \\
Deciduous mosaic & 10,976 & 3.8 & 10,976 & 3.8 & 0 & 0.0 \\
Forest regrowth & 1,282 & 0.4 & 1,282 & 0.4 & 0 & 0.0 \\
Non-wood & 15,630 & 5.4 & 15,455 & 5.3 & -176 & -0.1 \\
Wood/Shrub evergreen & 29,524 & 10.1 & 30,700 & 10.5 & 1,176 & 0.4 \\
Grassland & 3,809 & 1.3 & 3,659 & 1.3 & -149 & -0.0 \\
Wood/shrub dry & 91 & 0.0 & 91 & 0.0 & 0 & 0.0 \\
Mosaic of cropping $(<30 \%)$ & 5,288 & 1.8 & 5,288 & 1.8 & 0 & 0.0 \\
Mosaic of cropping $(>30 \%)$ & 2,682 & 0.9 & 3,471 & 1.2 & 790 & 0.3 \\
Agricultural land & 602 & 0.2 & 650 & 0.2 & 48 & 0.0 \\
Water surface & 16,930 & 5.8 & 17,417 & 6.0 & 488 & 0.2 \\
Total & 124 & 0.0 & 124 & 0.0 & 0 & 0.0 \\
\hline
\end{tabular}

Source: DFW (1998) 
(Maury-lechon and Curtet, 1998). Consequently the family contains $15-17$ genera or $470-580$ species. In Cambodia alone there are 5 genera or 23 species of Dipterocarp trees. The 5 genera includes Anisoptera (1 species), Dipterocarpus (7 species), Hopea (5 species), Shorea (7 species) and Vatica (3 species) (Table 2$)$. There are two major forest types in Cambodia - dryland and edaphic forests. Dipterocarps are the dominant species in all evergreen, mixed and deciduous forests of dryland forests.

\section{OVERVIEW OF STUDY SITE}

According to meteorological data, the provincial town of Kampong Thom's average rainfall was $1,305 \mathrm{~mm}$ and temperature $27.1^{\circ} \mathrm{C}$ between 1990 and 1993. Sandan is one of the seven districts of Kampong Thom, containing 9 communes or 71 villages. Sandan has a population of 37,098 of whom 19,023 are female. Nearly $75 \%$ of the population are engaged in farming and forestry for their livelihood. Sandan (Fig. 1) has a total land area of $291,498 \mathrm{ha}, 89 \%$ of which is forested. Forest area has declined from 261,974 ha in 1993 to 260,798 ha in 1997 . In terms of percentage, only $0.1 \%$ of the forest area has been converted to other forms of land use. By contrast, agricultural land has increased 488 ha or $0.04 \%$ per year over the same period (Table 3 ). The main economic development factors include logging, fishing and labor hire.

\section{ANALYTICAL RESULTS}

Before this two-year inventory project, evergreen forest in Sandan district had never been logged for any commercial purpose. Data used in this study were taken from 18 inventoried clusters (19.44ha). For all trees with DBH greater than $5 \mathrm{~cm}$, an average density of 1105.5 trees/ha and stand volume of $235.2 \mathrm{~m}^{3} /$ ha were recorded. Within these totals, dipterocarps comprised 194.1 trees and $107.1 \mathrm{~m}^{3}$, non-dipterocarps 405.1 trees and $70.6 \mathrm{~m}^{3}$, and unknown species 506.3 trees and $57.4 \mathrm{~m}^{3}$ for density and stand volume, respectively (Table 4 ). Table 4 also shows that mean stand density and stand volume per hectare varied from 982.5 trees and $96.6 \mathrm{~m}^{3}$ (No. 1) to $1,075.7$ trees and $210.9 \mathrm{~m}^{3}$ (No. 5), and to $1,290.4$ trees and $300.1 \mathrm{~m}^{3}$ (No. 12). In order to allow more accurate

Table 4 Mean stand density and volume per hectare in Sandan's evergreen forest ( $\mathrm{DBH} \geqq 5 \mathrm{~cm})$

\begin{tabular}{|c|c|c|c|c|c|c|c|c|}
\hline \multirow{2}{*}{$\begin{array}{c}\text { Sample } \\
\text { Cluster } \\
\text { No. }\end{array}$} & \multicolumn{2}{|c|}{ Dipterocarps } & \multicolumn{2}{|c|}{ Non-dipterocarp } & \multicolumn{2}{|c|}{ Unknown } & \multicolumn{2}{|c|}{ Total } \\
\hline & $\begin{array}{c}\text { Density } \\
\text { (trees) }\end{array}$ & $\begin{array}{c}\text { Volume } \\
\left(\mathrm{m}^{3}\right)\end{array}$ & $\begin{array}{c}\text { Density } \\
\text { (trees) }\end{array}$ & $\begin{array}{c}\text { Volume } \\
\left(\mathrm{m}^{3}\right)\end{array}$ & $\begin{array}{c}\text { Density } \\
\text { (trees) }\end{array}$ & $\begin{array}{c}\text { Volume } \\
\left(\mathrm{m}^{3}\right)\end{array}$ & $\begin{array}{c}\text { Density } \\
\text { (trees) }\end{array}$ & $\begin{array}{c}\text { Volume } \\
\left(\mathrm{m}^{3}\right)\end{array}$ \\
\hline \multicolumn{9}{|l|}{ Poor forest } \\
\hline 1 & 145.4 & 34.8 & 323.7 & 19.3 & 513.4 & 42.5 & 982.5 & 96.6 \\
\hline 2 & 111.1 & 34.9 & 363.2 & 70.6 & 437.2 & 27.8 & 911.5 & 133.3 \\
\hline 3 & 204.6 & 42.6 & 375.5 & 87.7 & 430.2 & 29.3 & 1010.3 & 159.6 \\
\hline 4 & 70.6 & 87.1 & 387.6 & 40.8 & 397.1 & 31.3 & 855.3 & 159.2 \\
\hline Mean & 132.9 & 49.9 & 362.5 & 54.6 & 444.5 & 32.7 & 939.9 & 137.2 \\
\hline \multicolumn{9}{|c|}{ Medium forest } \\
\hline 5 & 263.3 & 68.5 & 404.6 & 80.2 & 407.8 & 62.2 & 1075.7 & 210.9 \\
\hline 6 & 190.7 & 79.7 & 401.2 & 67.0 & 635.9 & 79.2 & 1227.8 & 225.9 \\
\hline 7 & 181.5 & 130.0 & 360.2 & 71.1 & 498.2 & 56.1 & 1039.9 & 257.2 \\
\hline 8 & 192.1 & 106.6 & 318.9 & 74.5 & 613.6 & 78.5 & 1124.6 & 259.6 \\
\hline 9 & 200.7 & 139.6 & 418.5 & 56.3 & 489.8 & 71.2 & 1109.0 & 267.1 \\
\hline 10 & 216.4 & 99.2 & 511.4 & 114.3 & 497.6 & 67.2 & 1225.4 & 280.7 \\
\hline 11 & 188.9 & 139.2 & 356.6 & 62.5 & 307.9 & 77.3 & 853.4 & 279.0 \\
\hline Mean & 204.8 & 109.0 & 395.9 & 75.1 & 493.0 & 70.2 & 1093.7 & 254.3 \\
\hline \multicolumn{9}{|l|}{ Rich forest } \\
\hline 12 & 322.0 & 134.3 & 410.6 & 70.8 & 557.8 & 95.0 & 1290.4 & 300.1 \\
\hline 13 & 145.4 & 169.6 & 478.2 & 56.0 & 611.1 & 76.4 & 1234.7 & 302.0 \\
\hline 14 & 232.9 & 165.3 & 328.5 & 68.5 & 592.1 & 70.4 & 1153.5 & 304.2 \\
\hline 15 & 193.5 & 129.7 & 354.4 & 126.5 & 562.3 & 51.0 & 1110.2 & 307.2 \\
\hline 16 & 233.3 & 151.6 & 522.6 & 87.1 & 575.2 & 76.5 & 1331.1 & 315.2 \\
\hline 17 & 317.6 & 183.8 & 586.8 & 96.0 & 469.2 & 41.1 & 1373.6 & 320.9 \\
\hline 18 & 267.6 & 203.6 & 516.7 & 69.2 & 703.3 & 75.5 & 1487.6 & 348.3 \\
\hline Mean & 244.6 & 162.6 & 456.8 & 82.0 & 581.6 & 69.4 & 1283.0 & 314.0 \\
\hline Mean (all) & 194.1 & 107.1 & 405.1 & 70.6 & 506.3 & 57.5 & 1105.5 & 235.2 \\
\hline
\end{tabular}


evaluation, Sandan's evergreen forest was further classified into poor (stand volume less than $200 \mathrm{~m}^{3} / \mathrm{ha}$ ), medium (stand volume between $200-300 \mathrm{~m}^{3} / \mathrm{ha}$ ) and rich forest (stand volume greater than $300 \mathrm{~m}^{3} /$ ha) (Fig. 2).

Poor forest

Poor forest comprised 4 of the total 18 clusters. On average per hectare, this forest has 939.9 trees and 137.2 $\mathrm{m}^{3}$, of which 132.9 trees (14.1\%) and $49.9 \mathrm{~m}^{3}(36.3 \%)$ were Dipterocarps. Non-dipterocarps trees were 362.5 trees (38.6\%) and $54.6 \mathrm{~m}^{3}$ (39.8\%), of which Myrtaceae, Ebanaceae and Caesalpinaceae were $12.8 \%$ and $9.8 \%$,
$6.4 \%$ and $2.0 \%$, and $4.0 \%$ and $6.8 \%$ for stand density and stand volume, respectively (Table 5 ). Approximately $39.8 \%$ of total trees and $55.5 \%$ of stand volume for trees of DBH greater than $45 \mathrm{~cm}$ belonged to the Dipterocarpaceae family (Table 5 ). The distribution of the stand volume across DBH classes clearly indicated that Dipterocarps mainly dominated the upper story and were therefore canopy and emergent trees.

In the four clusters, six dipterocarp species were recorded: CHBG, CRMS, PHDK, LMBI, CHRH and TRAC. Since the last three (LMBI, CHRH and TRAC) are rare in this forest, they were grouped into OTHR (others) for analysis purposes. For DBH less than $45 \mathrm{~cm}$,
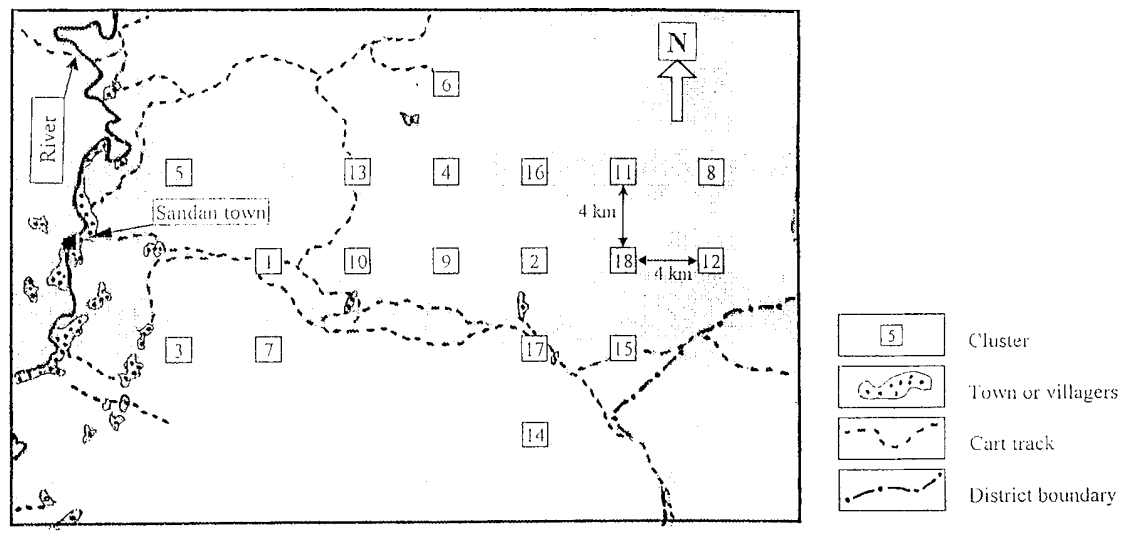

Fig. 2 Map of inventoried clusters

Table 5 Mean stand density and stand volume per hectare of poor evergreen forest

\begin{tabular}{|c|c|c|c|c|c|c|c|c|c|c|c|c|}
\hline \multirow{3}{*}{ Family } & \multicolumn{4}{|c|}{ Total $(\mathrm{DBH}<45 \mathrm{~cm})$} & \multicolumn{4}{|c|}{ Total $(\mathrm{DBH} \geqq 45 \mathrm{~cm})$} & \multicolumn{4}{|c|}{ Total $(\mathrm{DBH} \geqq 5 \mathrm{~cm})$} \\
\hline & \multicolumn{2}{|c|}{ Density } & \multicolumn{2}{|c|}{ Volume } & \multicolumn{2}{|c|}{ Density } & \multicolumn{2}{|c|}{ Volume } & \multicolumn{2}{|c|}{ Density } & \multicolumn{2}{|c|}{ Volume } \\
\hline & trees & $\%$ & $\mathrm{~m}^{3}$ & $\%$ & trees & $\%$ & $\mathrm{~m}^{3}$ & $\%$ & trees & $\%$ & $\mathrm{~m}^{3}$ & $\%$ \\
\hline Dipterocarpaceae & 125.7 & 13.6 & 11.8 & 17.2 & 7.2 & 39.8 & 38.1 & 55.5 & 132.9 & 14.1 & 49.9 & 36.3 \\
\hline Myrtaceae & 119.7 & 13.0 & 11.6 & 16.9 & 0.9 & 5.2 & 1.8 & 2.7 & 120.6 & 12.8 & 13.5 & 9.8 \\
\hline Ebenaceae & 60.0 & 6.5 & 2.8 & 4.1 & 0.0 & 0.0 & 0.0 & 0.0 & 60.0 & 6.4 & 2.8 & 2.0 \\
\hline Caesalpinaceae & 36.1 & 3.9 & 5.5 & 8.0 & 1.6 & 9.0 & 3.9 & 5.6 & 37.7 & 4.0 & 9.4 & 6.8 \\
\hline Euphorbiaceae & 33.1 & 3.6 & 3.4 & 5.0 & 0.5 & 2.5 & 0.8 & 1.2 & 33.6 & 3.6 & 4.3 & 3.1 \\
\hline Rosaceae & 23.2 & 2.5 & 3.1 & 4.5 & 1.4 & 7.6 & 5.3 & 7.8 & 24.5 & 2.6 & 8.4 & 6.1 \\
\hline Rhizophoraceae & 17.6 & 1.9 & 1.0 & 1.4 & 0.0 & 0.0 & 0.0 & 0.0 & 17.6 & 1.9 & 1.0 & 0.7 \\
\hline Sapotaceae & 13.4 & 1.5 & 1.4 & 2.0 & 0.2 & 1.4 & 0.4 & 0.6 & 13.6 & 1.5 & 1.8 & 1.3 \\
\hline Hypericaceae & 13.4 & 1.5 & 1.8 & 2.6 & 0.0 & 0.0 & 0.0 & 0.0 & 13.4 & 1.4 & 1.8 & 1.3 \\
\hline Crypteroniaceae & 10.7 & 1.2 & 2.3 & 3.4 & 1.4 & 7.7 & 3.6 & 5.2 & 12.0 & 1.3 & 5.9 & 4.3 \\
\hline Meliaceae & 9.0 & 1.0 & 0.5 & 0.7 & 0.0 & 0.0 & 0.0 & 0.0 & 9.0 & 1.0 & 0.5 & 0.3 \\
\hline Clusiaceae & 5.1 & 0.6 & 0.3 & 0.5 & 0.5 & 2.5 & 1.0 & 1.4 & 5.6 & 0.6 & 1.3 & 0.9 \\
\hline Lauraceae & 5.1 & 0.6 & 1.5 & 2.1 & 0.0 & 0.0 & 0.0 & 0.0 & 5.1 & 0.5 & 1.5 & 1.1 \\
\hline Sterculiaceae & 3.9 & 0.4 & 0.5 & 0.8 & 0.2 & 1.3 & 0.9 & 1.4 & 4.2 & 0.4 & 1.5 & 1.1 \\
\hline Lythraceae & 3.0 & 0.3 & 0.3 & 0.4 & 0.0 & 0.0 & 0.0 & 0.0 & 3.0 & 0.3 & 0.3 & 0.2 \\
\hline Fagaceae & 2.1 & 0.2 & 0.2 & 0.3 & 0.0 & 0.0 & 0.0 & 0.0 & 2.1 & 0.2 & 0.2 & 0.2 \\
\hline Combretaceae & 0.2 & 0.0 & 0.2 & 0.2 & 0.2 & 1.3 & 0.6 & 0.8 & 0.5 & 0.0 & 0.7 & 0.5 \\
\hline Unknown & 440.5 & 47.8 & 20.5 & 29.8 & 3.9 & 21.8 & 12.3 & 17.8 & 444.5 & 47.3 & 32.7 & 23.9 \\
\hline Total & 921.8 & 100.0 & 68.5 & 100.0 & 18.1 & 100.0 & 68.7 & 100.0 & 939.9 & 100.0 & 137.2 & 100.0 \\
\hline
\end{tabular}


125.9 trees (stand density) and $1.8 \mathrm{~m}^{3}$ (stand volume) were recorded, of which CRMS, CHBG and PHDK comprised 108.6 trees $(86.3 \%)$ and $8.1 \mathrm{~m}^{3}(68.6 \%), 6.3$ trees $(5.0 \%)$ and $1.4 \mathrm{~m}^{3}(11.9 \%)$, and 10.5 trees $(8.3 \%)$ and $1.8 \mathrm{~m}^{3}(15.3 \%)$, respectively, while OTHR covered the rest
(Fig. 3 ). For DBH greater than $45 \mathrm{~cm}, 7.1$ trees and $38.1 \mathrm{~m}^{3}$ were recorded, of which PHDK, CHBG and CRMS were 4.0 trees $(56.3 \%)$ and $\left.24.5 \mathrm{~m}^{3} 64.3 \%\right), 2.7$ trees $(38 \%)$ and $12.4 \mathrm{~m}^{3}(35.2 \%)$, and 0 trees, respectively, and the rest was OTHR (Fig. 3 ). Based on Fig 3, it can be

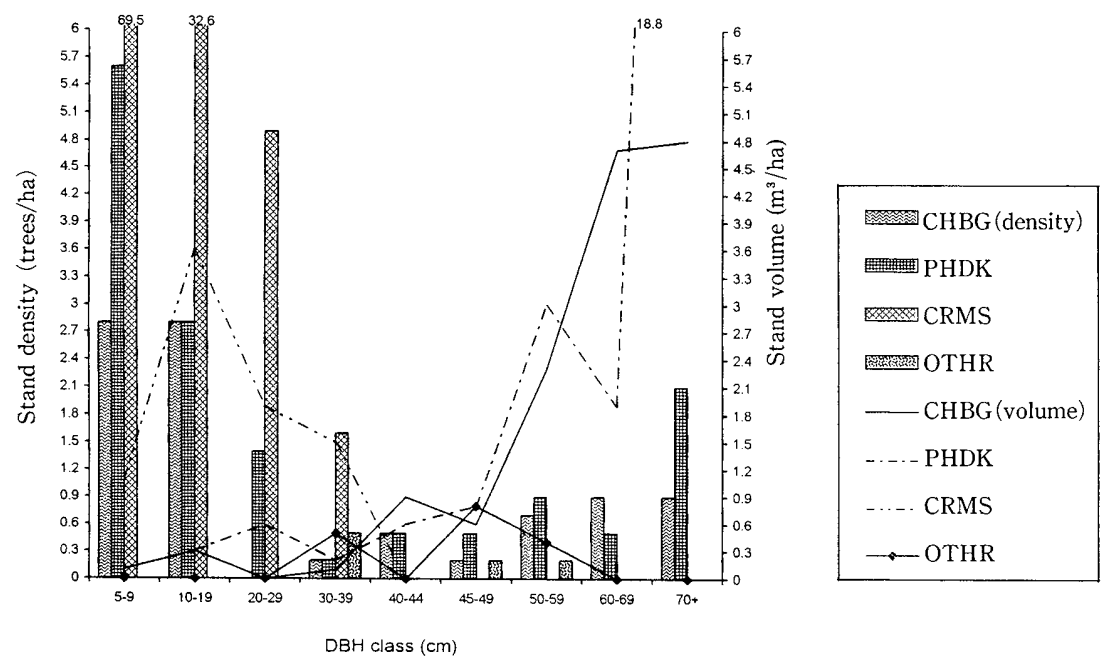

Fig. 3 Distribution of mean stand density and volume of dipterocarps in poor overgreen forest by DBH class

Table 6 Mean stand density and volume per hectare of medium evergreen forest

\begin{tabular}{|c|c|c|c|c|c|c|c|c|c|c|c|c|}
\hline \multirow{3}{*}{ Family } & \multicolumn{4}{|c|}{ Total $(\mathrm{DBH}<45 \mathrm{~cm})$} & \multicolumn{4}{|c|}{ Total $(\mathrm{DBH} \geqq 45 \mathrm{~cm})$} & \multicolumn{4}{|c|}{ Total $(\mathrm{DBH} \geqq 5 \mathrm{~cm})$} \\
\hline & \multicolumn{2}{|c|}{ Density } & \multicolumn{2}{|c|}{ Volume } & \multicolumn{2}{|c|}{ Density } & \multicolumn{2}{|c|}{ Volume } & \multicolumn{2}{|c|}{ Density } & \multicolumn{2}{|c|}{ Volume } \\
\hline & trees & $\%$ & $\mathrm{~m}^{3}$ & $\%$ & trees & $\%$ & $\mathrm{~m}^{3}$ & $\%$ & trees & $\%$ & $\mathrm{~m}^{3}$ & $\%$ \\
\hline Dipterocarpaceae & 188.7 & 17.9 & 22.4 & 21.2 & 16.1 & 43.9 & 86.6 & 58.2 & 204.8 & 18.7 & 109.0 & 42.8 \\
\hline Myrtaceae & 115.5 & 10.9 & 16.9 & 16.0 & 2.8 & 7.6 & 5.7 & 3.8 & 118.3 & 10.8 & 22.6 & 8.9 \\
\hline Ebenaceae & 102.8 & 9.7 & 3.8 & 3.6 & 0.0 & 0.0 & 0.0 & 0.0 & 102.8 & 9.4 & 3.8 & 1.5 \\
\hline Euphorbiaceae & 63.6 & 6.0 & 5.4 & 5.1 & 0.7 & 1.8 & 1.3 & 0.8 & 64.3 & 5.9 & 6.6 & 2.6 \\
\hline Caesalpinaceae & 18.3 & 1.7 & 3.0 & 2.8 & 2.0 & 5.4 & 6.0 & 4.0 & 20.2 & 1.8 & 9.0 & 3.5 \\
\hline Clusiaceae & 19.3 & 1.8 & 2.2 & 2.1 & 0.7 & 1.8 & 1.5 & 1.0 & 20.0 & 1.8 & 3.8 & 1.5 \\
\hline Meliaceae & 18.0 & 1.7 & 1.0 & 0.9 & 0.0 & 0.0 & 0.0 & 0.0 & 18.0 & 1.6 & 1.0 & 0.4 \\
\hline Lauraceae & 12.8 & 1.2 & 1.5 & 1.4 & 0.0 & 0.0 & 0.0 & 0.0 & 12.8 & 1.2 & 1.5 & 0.6 \\
\hline Sterculiaceae & 7.3 & 0.7 & 1.2 & 1.1 & 0.9 & 2.5 & 6.7 & 4.5 & 8.2 & 0.8 & 7.8 & 3.1 \\
\hline Rosaceae & 4.3 & 0.4 & 2.0 & 1.9 & 2.9 & 7.9 & 9.0 & 6.1 & 7.2 & 0.7 & 11.0 & 4.3 \\
\hline Crypteroniaceae & 6.1 & 0.6 & 2.6 & 2.5 & 0.0 & 0.0 & 0.0 & 0.0 & 6.1 & 0.6 & 2.6 & 1.0 \\
\hline Rhizophoraceae & 3.6 & 0.3 & 0.2 & 0.2 & 0.1 & 0.4 & 0.3 & 0.2 & 3.7 & 0.3 & 0.5 & 0.2 \\
\hline Hypericaceae & 3.6 & 0.3 & 0.1 & 0.1 & 0.0 & 0.0 & 0.0 & 0.0 & 3.6 & 0.3 & 0.1 & 0.0 \\
\hline Lythraceae & 2.3 & 0.2 & 0.3 & 0.3 & 0.3 & 0.7 & 0.5 & 0.3 & 2.5 & 0.2 & 0.8 & 0.3 \\
\hline Sapotaceae & 1.2 & 0.1 & 1.0 & 0.9 & 0.7 & 1.8 & 2.0 & 1.4 & 1.9 & 0.2 & 3.0 & 1.2 \\
\hline Verbenaceae & 1.6 & 0.2 & 0.0 & 0.0 & 0.0 & 0.0 & 0.0 & 0.0 & 1.6 & 0.1 & 0.0 & 0.0 \\
\hline Ochanaceae & 1.6 & 0.2 & 0.0 & 0.0 & 0.0 & 0.0 & 0.0 & 0.0 & 1.6 & 0.1 & 0.0 & 0.0 \\
\hline Moraceae & 1.5 & 0.1 & 0.5 & 0.5 & 0.1 & 0.4 & 0.3 & 0.2 & 1.6 & 0.1 & 0.8 & 0.3 \\
\hline Combretaceae & 0.8 & 0.1 & 0.3 & 0.2 & 0.0 & 0.0 & 0.0 & 0.0 & 0.8 & 0.1 & 0.3 & 0.1 \\
\hline Anacardiaceae & 0.8 & 0.1 & 0.1 & 0.0 & 0.0 & 0.0 & 0.0 & 0.0 & 0.8 & 0.1 & 0.1 & 0.0 \\
\hline Fagaceae & 0.1 & 0.0 & 0.1 & 0.1 & 0.0 & 0.0 & 0.0 & 0.0 & 0.1 & 0.0 & 0.1 & 0.0 \\
\hline Unknown & 483.5 & 45.7 & 41.2 & 39.0 & 9.5 & 25.9 & 29.0 & 19.5 & 493.0 & 45.1 & 70.2 & 27.6 \\
\hline Total & $1,057.0$ & 100.0 & 105.6 & 100.0 & 36.7 & 100.0 & 148.7 & 100.0 & $1,093.8$ & 100.0 & 254.3 & 100.0 \\
\hline
\end{tabular}


said that poor forest is comprised of three layers of dipterocarps-the upper layer (PHDK and $\mathrm{CHBG}$ ), the middle layer (CRMS) and low layer (OTHR). The presence of TRAC here meant that this forest has been gradually converted to mixed and deciduous forests. In Cambodia, TRAC is usually found in deciduous forest.

\section{Medium forest}

In the seven clusters, the average per hectare of stand density and stand volume recorded were 1,093.7 trees $(\mathrm{DBH} \geq 5 \mathrm{~cm})$ and $254.3 \mathrm{~m}^{3}$ of which dipterocarps, non -dipterocarps and unknown trees contributed $18.7 \%$ and $42.8 \%, 36.2 \%$ and $29.6 \%$, and $45.1 \%$ and 27.6 for stand density and stand volume, respectively. Non-dipterocarps comprised Myrtaceae 118.3 trees (10.8\%), Ebenaceae 102.8 trees $(9.4 \%)$, Euphorbiaceae 64.3 trees $(5.9 \%)$, etc. (Table 6 ). For stand density and stand volume of trees with $\mathrm{DBH}<45 \mathrm{~cm}$, dipterocarps comprised 188.7 trees $(17.9 \%)$ and $22.4 \mathrm{~m}^{3}(21.2 \%)$, non-dipterocarps 384.8 trees $(36.5 \%)$ and $42.0 \mathrm{~m}^{3}(39.9 \%)$ and unknown trees 483.5 trees $(45.7 \%)$ and $41.2 \mathrm{~m}^{3}(39.0 \%)$, respectively (Table 6). For the DBH class greater than $45 \mathrm{~cm}$, the figures for mean stand density and stand volume of dipterocarps, non-dipterocarps and unknown trees, respectively, were 16.1 trees $(43.9 \%)$ and $86.6 \mathrm{~m}^{3} \quad(58.2 \%)$,
11.1 trees $(30.2 \%)$ and $33.1 \mathrm{~m}^{3}(22.3 \%)$, and 9.5 trees $(25.9 \%)$ and $29.0 \mathrm{~m}^{3}(19.5 \%)$ (Table 6$)$. The larger the diameter, the more dominant were the dipterocarps.

In the seven clusters, nine dipterocarp species were recorded, namely $\mathrm{CHBG}$, CRMS, PHDK, CHRH, PPEL, KKKS, LMBI, TRAC and TRLT, with an average of 204.8 trees/ha and $109.0 \mathrm{~m}^{3} /$ ha for stand density and stand volume. The last four species were grouped into OTHR (others). With respects to stand density and stand volume $(\mathrm{DBH}<45 \mathrm{~cm})$, CRMS, CHBG and PHDK comprised 137.8 trees $(73.0 \%)$ and $13.3 \mathrm{~m}^{3} \quad(59.2 \%), 8.5$ trees $(4.5 \%)$ and $3.6 \mathrm{~m}^{3}(16.0 \%)$, and 21.2 trees $(11.2 \%)$ and $3.5 \mathrm{~m}^{3}(15.8 \%)$, respectively, while CHRH, PPEL and OTHR shared the rest. For DBH greater than $45 \mathrm{~cm}$, CRMS was only 0.9 trees $(5.7 \%)$ and $3.6 \mathrm{~m}^{3}(4.2 \%)$, PHDK and CHBG were $36.1 \%$ and $40.3 \%$, and $49.3 \%$ and $50.8 \%$ for density and stand volume, respectively (Fig. 4).

\section{Rich forest}

There were seven clusters of rich forest, with average stand density of $1,283.0$ trees/ha and volume 314.0 $\mathrm{m}^{3} /$ ha for trees of $\mathrm{DBH} \geq 5 \mathrm{~cm}$. Of these, dipterocarps, non -dipterocarps and unknown trees contributed 244.6 trees $(19.1 \%)$ and $165.7 \mathrm{~m}^{3}(52.8 \%) \quad 456.8$ trees $\left.35.6 \%\right)$ and

Table 7 Mean stand density and volume per hectare of rich evergreen forest

\begin{tabular}{|c|c|c|c|c|c|c|c|c|c|c|c|c|}
\hline \multirow{3}{*}{ Family } & \multicolumn{4}{|c|}{ Total $(\mathrm{DBH}<45 \mathrm{~cm})$} & \multicolumn{4}{|c|}{ Total $(\mathrm{DBH} \geqq 45 \mathrm{~cm})$} & \multicolumn{4}{|c|}{ Total $(\mathrm{DBH} \geqq 5 \mathrm{~cm})$} \\
\hline & \multicolumn{2}{|c|}{ Density } & \multicolumn{2}{|c|}{ Volume } & \multicolumn{2}{|c|}{ Density } & \multicolumn{2}{|c|}{ Volume } & \multicolumn{2}{|c|}{ Density } & \multicolumn{2}{|c|}{ Volume } \\
\hline & trees & $\%$ & $\mathrm{~m}^{3}$ & $\%$ & trees & $\%$ & $\mathrm{~m}^{3}$ & $\%$ & trees & $\%$ & $\mathrm{~m}^{3}$ & $\%$ \\
\hline Dipterocarpaceae & 224.1 & 18.0 & 32.8 & 28.3 & 20.5 & 52.0 & 132.9 & 67.1 & 244.6 & 19.1 & 165.7 & 52.8 \\
\hline Myrtaceae & 174.6 & 14.0 & 12.0 & 10.3 & 1.7 & 4.3 & 4.6 & 2.3 & 176.3 & 13.7 & 16.6 & 5.3 \\
\hline Ebenaceae & 101.8 & 8.2 & 3.2 & 2.7 & 0.3 & 0.7 & 0.6 & 0.3 & 102.1 & 8.0 & 3.7 & 1.2 \\
\hline Euphorbiaceae & 46.6 & 3.7 & 2.0 & 1.7 & 0.4 & 1.1 & 0.5 & 0.3 & 47.0 & 3.7 & 2.5 & 0.8 \\
\hline Clusiaceae & 18.7 & 1.5 & 3.6 & 3.1 & 0.3 & 0.7 & 0.5 & 0.2 & 18.9 & 1.5 & 4.0 & 1.3 \\
\hline Lauraceae & 16.8 & 1.4 & 1.0 & 0.9 & 0.0 & 0.0 & 0.0 & 0.0 & 16.8 & 1.3 & 1.0 & 0.3 \\
\hline Caesalpinaceae & 13.6 & 1.1 & 3.3 & 2.8 & 2.1 & 5.4 & 9.1 & 4.6 & 15.7 & 1.2 & 12.3 & 3.9 \\
\hline Meliaceae & 11.0 & 0.9 & 0.5 & 0.4 & 0.0 & 0.0 & 0.0 & 0.0 & 11.0 & 0.9 & 0.5 & 0.1 \\
\hline Crypteroniaceae & 9.4 & 0.8 & 3.6 & 3.1 & 0.1 & 0.3 & 0.6 & 0.3 & 9.5 & 0.7 & 4.2 & 1.3 \\
\hline Rhizophoraceae & 9.4 & 0.8 & 3.3 & 2.8 & 0.0 & 0.0 & 0.0 & 0.0 & 9.4 & 0.7 & 3.3 & 1.0 \\
\hline Sapotaceae & 7.7 & 0.6 & 2.3 & 2.0 & 1.3 & 3.4 & 3.8 & 1.9 & 9.0 & 0.7 & 6.0 & 1.9 \\
\hline Anacardiaceae & 8.5 & 0.7 & 0.7 & 0.6 & 0.0 & 0.0 & 0.0 & 0.0 & 8.5 & 0.7 & 0.7 & 0.2 \\
\hline Fagaceae & 7.5 & 0.6 & 0.3 & 0.2 & 0.0 & 0.0 & 0.0 & 0.0 & 7.5 & 0.6 & 0.3 & 0.1 \\
\hline Sterculiaceae & 6.3 & 0.5 & 2.1 & 1.8 & 1.1 & 2.7 & 5.0 & 2.5 & 7.4 & 0.6 & 7.1 & 2.2 \\
\hline Rosaceae & 5.2 & 0.4 & 3.8 & 3.3 & 2.1 & 5.4 & 6.1 & 3.1 & 7.3 & 0.6 & 9.9 & 3.2 \\
\hline Mimosae & 3.6 & 0.3 & 0.1 & 0.0 & 0.0 & 0.0 & 0.0 & 0.0 & 3.6 & 0.3 & 0.1 & 0.0 \\
\hline Moraceae & 3.4 & 0.3 & 0.5 & 0.4 & 0.0 & 0.0 & 0.0 & 0.0 & 3.4 & 0.3 & 0.5 & 0.1 \\
\hline Lythraceae & 2.5 & 0.2 & 0.2 & 0.2 & 0.0 & 0.0 & 0.0 & 0.0 & 2.5 & 0.2 & 0.2 & 0.1 \\
\hline Mimosaceae & 0.5 & 0.0 & 0.2 & 0.2 & 0.0 & 0.0 & 0.0 & 0.0 & 0.5 & 0.0 & 0.2 & 0.1 \\
\hline Anonaceae & 0.4 & 0.0 & 0.0 & 0.0 & 0.0 & 0.0 & 0.0 & 0.0 & 0.4 & 0.0 & 0.0 & 0.0 \\
\hline Unknown & 572.1 & 46.0 & 40.8 & 35.2 & 9.5 & 24.2 & 34.4 & 17.4 & 581.6 & 45.3 & 75.2 & 24.0 \\
\hline Total & $1,243.6$ & 100.0 & 116.1 & 100.0 & 39.4 & 100.0 & 198.0 & 100.0 & $1,283.0$ & 100.0 & 314.0 & 100.0 \\
\hline
\end{tabular}


$73.1 \mathrm{~m}^{3}(23.2 \%)$, and 581.6 trees $(45.3 \%)$ and $75.2 \mathrm{~m}^{3}$ $(24.0 \%)$, respectively. Non-dipterocarps comprised Myrtaceae 176.3 trees (13.7\%), Ebenaceae 102.1 trees (8.0\%), Euphorbiaceae 47.0 trees $(3.7 \%$ ), etc (Table 7 ). In east Kalimantan, Indonesia, by comparison, an average stand volume of $402 \mathrm{~m}^{3} /$ ha $(\mathrm{DBH}>10 \mathrm{~cm})$ was recorded (Sist and Saridan, 1998). On average per hectare for trees of DBH less than $45 \mathrm{~cm}$, Dipterocarps comprised 224.1 trees $(18 . \%)$ and $32.8 \mathrm{~m}^{3}(28.3 \%)$, non-dipterocarps were 477.4 trees $(36 . \%)$ and $43.3 \mathrm{~m}^{3}(36.5 \%)$, and unknown trees 572.1 trees $(46.0 \%)$ and $40.8 \mathrm{~m}^{3}(35.2 \%)$, for mean stand density and stand volume, respectively (Table 7 ). For DBH class greater than $45 \mathrm{~cm}$, dipterocarps were 20.5 trees $(52.0 \%)$ and $132.9 \mathrm{~m}^{3}(67.1 \%)$, non-dipterocarps 9.4 trees $(23.8 \%)$ and $30.5 \mathrm{~m}^{3}(15.5 \%)$, and unknown trees 9.5 trees $(24.2 \%)$ and $34.4 \mathrm{~m}^{3}(17.4 \%)$ for stand density and stand volume, respectively (Table 7 ).

From the detailed analysis of the seven clusters, six dipterocarps species were found: CHBG, CRMS, PHDK, CHRH and OTHR (KKTM and LMBI) with an average mean stand density and stand volume of 244.6 trees/ha and $165.7 \mathrm{~m}^{3} /$ ha. For DBH less than $45 \mathrm{~cm}$, CRMS, CHBG and PHDK comprised 178.3 trees $\left(79.6 \%\right.$ ) and $22.9 \mathrm{~m}^{3}$ $(69.8 \%), 17.0$ trees $(7.6 \%)$ and $3.5 \mathrm{~m}^{3}(10.7 \%)$, and 23.2 trees $(10.4 \%)$ and $4.6 \mathrm{~m}^{3}(14.0 \%)$, respectively, while other species shared the rest (Fig. 5). For DBH greater than $45 \mathrm{~cm}, \mathrm{CRMS}, \mathrm{CHBG}$ and PHDK were 0.6 trees $(2.9 \%)$ and $1.9 \mathrm{~m}^{3}(1.4 \%), 10.2$ trees $(49.8 \%)$ and $65.8 \mathrm{~m}^{3}(49.5 \%)$, and 8.7 trees $(42.4 \%)$ and $60.6 \mathrm{~m}^{3}$ (45.6\%) respectively, and CHRH and OTHR shared the

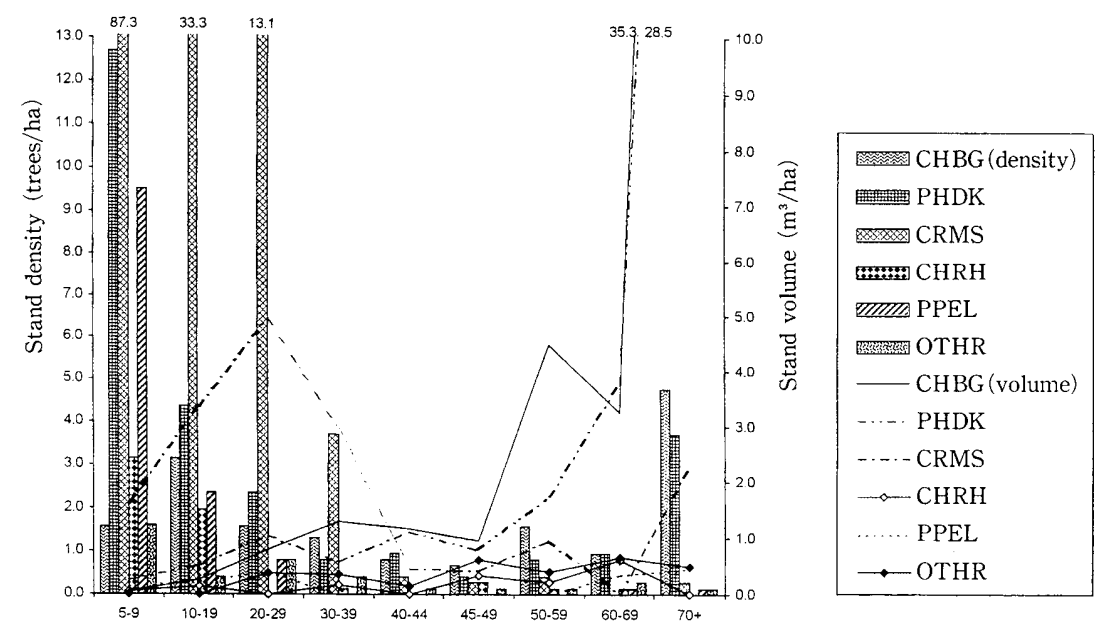

Fig. 4 Distribution of mean stand density and volume of dipterocarps in medium evergreen forest by DBH class

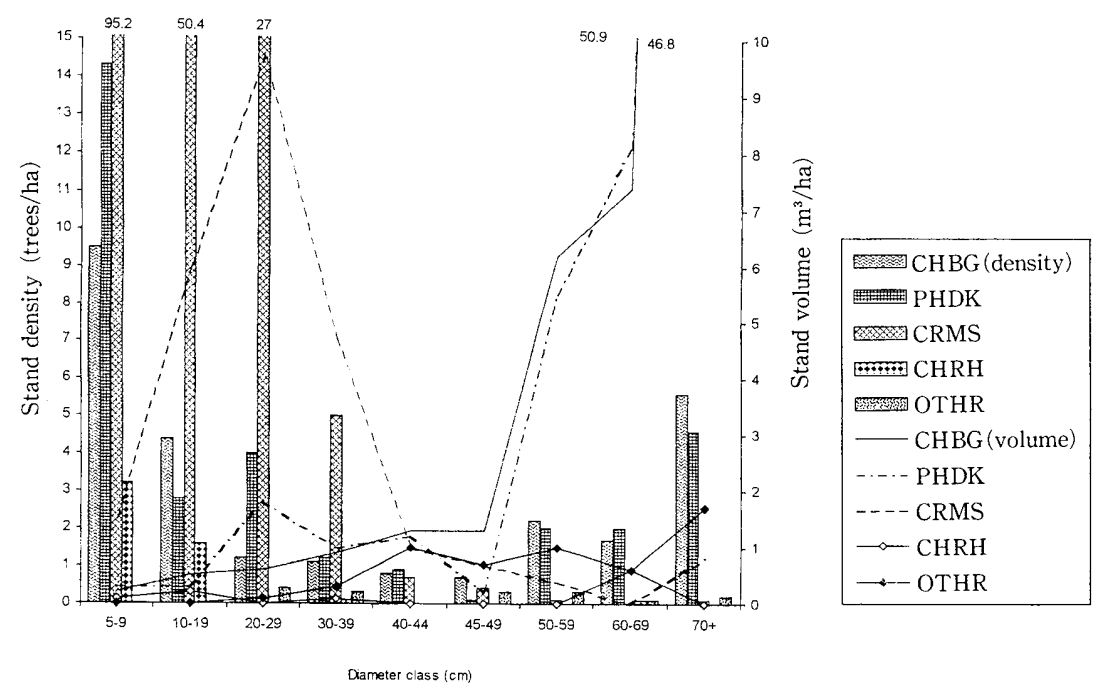

Fig. 5 Distribution of mean stand density and volume of dipterocarps in rich evergreen forest by DBH class 
rest (Fig. 5 ).

\section{MANAGEMENT SYSTEMS IN SOME SELECTED COUNTRIES IN SOUTHEAST ASIA}

Forest management in neighboring countries, Vietnam and Thailand

Forests in Vietnam are classified into three main types based on the stand volume per hectare, namely rich (more than $\left.150 \mathrm{~m}^{3}\right)$, medium $\left(80-150 \mathrm{~m}^{3}\right)$ and poor (less than $80 \mathrm{~m}^{3}$ ) forests. The harvest volume per hectare is 24 $\mathrm{m}^{3} /$ ha on average (VAN, 1999). Further information on forest management in Vietnam is not available at present.

A selective cutting cycle of 30 years is implemented in Thailand. With a mean annual increment of $1 \mathrm{~m}^{3} / \mathrm{ha} /$ year or $2 \%$ of standing volume (ITTO, 1994), the annual allowable cut per hectare is $30 \mathrm{~m}^{3}$ for evergreen and semi -evergreen forests, $80 \mathrm{~m}^{3}$ for dry mixed deciduous with teak and $45 \mathrm{~m}^{3}$ for those without teak, and $20 \mathrm{~m}^{3}$ for dry dipterocarp forest (FAO and UNEP, 1981). Evergreen forest is distributed through southern and eastern regions (near Cambodian border) where annual rainfall exceeds 2,000 $\mathrm{mm}$, while semi-evergreen forests is distributed throughout the country where rainfall is around $1,000-2000 \mathrm{~mm} /$ year (SutTHisRinn, 1999).
Forest management in Malaysia

i ) Malayan Uniform System (MUS)

Basically it is a system for converting the virgin tropical lowland rain forest to a more or less even-aged forest, containing a greater proportion of the commercial species. This is achieved by a clear-felling release of selected natural generation of varying ages, aided by systematic poison-girdling of defective and non-commercial species. This system has been successfully applied to the lowland dipterocarp forest, particularly in peninsular Malaysia. The cutting volume is set at $40 \mathrm{~m}^{3} /$ ha of trees with $\mathrm{DBH}$ greater than $45 \mathrm{~cm}$.

ii ) Selective Management System (SMS)

SMS was introduced in 1978, when it was found that MUS was not suitable for hill dipterocarp forest because of the comparatively more difficult terrain, uneven stocking, lack of natural regeneration before logging and uncertain seedling regeneration after logging (ITTO, 1994). SMS allows for more flexible timber harvesting regimes which are consistent with the need to safeguard the environment and at the same time to take advantage of the demands of the timber market. Under SMS the next cut is expected in 25-30 years after the first harvesting with an expected net economic outturn of $30-40 \mathrm{~m}^{3} /$ ha enriched with dipterocarp species. The cutting limits prescribed for the group of dipterocarp species are that trees cut should not be less

Table 8 Harvest potential per hectare of Sandan's evergreen forest

\begin{tabular}{|c|c|c|c|c|c|c|c|c|}
\hline \multirow[b]{2}{*}{$\begin{array}{l}\text { Species } \\
\text { code }\end{array}$} & \multicolumn{2}{|c|}{ Poor forest } & \multicolumn{2}{|c|}{ Medium forest } & \multicolumn{2}{|c|}{ Rich forest } & \multicolumn{2}{|c|}{ Average } \\
\hline & $\begin{array}{c}\text { Density } \\
\text { (trees/ha) }\end{array}$ & $\begin{array}{l}\text { Volume } \\
\left(\mathrm{m}^{3} / \mathrm{ha}\right)\end{array}$ & $\begin{array}{c}\text { Density } \\
\text { (trees/ha) }\end{array}$ & $\begin{array}{l}\text { Volume } \\
\left(\mathrm{m}^{3} / \mathrm{ha}\right)\end{array}$ & $\begin{array}{c}\text { Density } \\
\text { (trees) }\end{array}$ & $\begin{array}{c}\text { Volume } \\
\left(\mathrm{m}^{3}\right)\end{array}$ & $\begin{array}{c}\text { Density } \\
\text { (trees/ha) }\end{array}$ & $\begin{array}{l}\text { Volume } \\
\left(\mathrm{m}^{3} / \mathrm{ha}\right)\end{array}$ \\
\hline CHBG & 1.8 & 9.5 & 5.7 & 38.6 & 7.3 & 58.3 & 4.9 & 35.5 \\
\hline PHDK & 4.0 & 24.5 & 5.8 & 34.9 & 8.7 & 60.6 & 6.2 & 40.0 \\
\hline CRMS & 1.6 & 1.5 & 5.0 & 7.0 & 6.3 & 7.6 & 4.3 & 5.4 \\
\hline OTHR & (P) 0.4 & ${ }^{(\mathrm{P})} 1.2$ & (M) 1.4 & ${ }^{(\mathrm{M})} 4.1$ & ${ }^{(\mathrm{R})} 1.0$ & ${ }^{(\mathrm{R})} 4.6$ & 0.9 & 3.3 \\
\hline Subtotal & 7.8 & 36.7 & 18.0 & 84.5 & 23.3 & 131.1 & 16.4 & 84.1 \\
\hline $30 \%$ cut & 2.3 & 11.0 & 5.4 & 25.4 & 7.0 & 39.3 & 4.9 & 25.2 \\
\hline Non-dipterocarp & 6.9 & 18.3 & 11.1 & 22.3 & 9.3 & 15.5 & 9.1 & 18.7 \\
\hline Unknown & 3.9 & 12.3 & 9.5 & 29.0 & 9.5 & 34.4 & 7.6 & 25.2 \\
\hline Subtotal & 10.8 & 30.6 & 20.6 & 51.2 & 18.9 & 49.9 & 16.8 & 43.9 \\
\hline $30 \%$ cut & 3.2 & 9.2 & 6.2 & 15.4 & 5.7 & 15.0 & 5.0 & 13.2 \\
\hline Grand total & 18.6 & 67.3 & 38.6 & 135.7 & 42.2 & 181.0 & 33.1 & 128.0 \\
\hline $30 \%$ cut & 5.6 & 20.2 & 11.6 & 40.8 & 12.7 & 54.3 & 10.0 & 38.4 \\
\hline
\end{tabular}

Note: The diameter limits for harvest: $C H B G \geqq 60 \mathrm{~cm}$, PHDK $\geqq 45$, CRMS $\geqq 30$, OTHR (assumed for all) $\geqq 45 \mathrm{~cm}$, nondipterocarps and unknown (assumed) $\geqq 45 \mathrm{~cm}$

OTHR $^{(\mathrm{P})}:$ LMBI, CHRH, TRAC

OTHR $^{(M)}$ : CHRH, PPEL, KKKS, LMBI, TRAC and TRLT

$\mathrm{OTHR}^{(\mathrm{R})}$ : CHRH, KKTM, LMBI 
than $50 \mathrm{~cm} \mathrm{DBH}$, and for non-dipterocarp species not less than $45 \mathrm{~cm} \mathrm{DBH}$, and the residual stocking should have at least 32 sound commercial trees per hectare.

Forest management in Indonesia

Until recently, no detailed data on growth rates of natural stands were available for Indonesia. For dipterocarp forests, estimates of $1-2 \mathrm{~m}^{3} / \mathrm{ha} /$ year in currently commercial species have been made. In such places as Sulawesi, Maluku and Irian Java, the commercial growth in the forests is assessed at less than $1 \mathrm{~m}^{3} / \mathrm{ha}$ /year (FAO and UNEP, 1981). There are two forest management systems in Indonesia: the Indonesian selective cutting system and Indonesian selective felling and replanting.

\section{i) Indonesian selective cutting system (TPI)}

Before 1988 this was the main management system which prescribed minimum cutting diameter according to forest type. Under TPI, concessionaires were required to contribute a deposit to a reforestation fund, which was refundable after they carried out the reforestation work prescribed. The system, however, was found to be impractical as only $10 \%$ of the concessionaires complied with the regeneration requirements on only $6 \%$ of the area logged. Simply, the cost for regeneration was much higher than the contribution to the reforestation fund. The TPI was then modified to require replanting, which is called Indonesian selective felling and replanting (TPTI). The TPTI was formulated to manage natural production forest with adequate young trees for regeneration.

\section{ii) Indonesian selective felling and replanting (TPTI)}

Under TPTI, forest concessionaires are required to manage their concession areas on a 35-year cutting cycle. Therefore, the annual allowable cut is based on this cutting cycle and the area given. Tree felling is bound by regulations on the minimum diameter to be cut and leaving behind a certain number of trees of certain diameter for future stock. Guidelines for TPTI which were prepared by the ministry of forestry required loggers to submit plans for inventory, road construction, felling, residual stand inventory and replanting, and protect 25 mother commercial species trees per hectare. On average, approximately 7-8 trees/ha were extracted (ITTO, 1994, Indonesia). In east Kalimantan under this system, dipterocarp forest is capable of growing about $1.3 \mathrm{~m}^{3} /$ ha/year.

\section{HARVEST POTENTIAL OF SANDAN'S EVERGREEN FOREST}

Understanding the harvesting potential of a forest is a prime consideration for forest management and forest investment. As mentioned in KIM PHAT (1999), in the selective cutting systems applied to Cambodian forests, harvesting intensity is expressed in terms of the volume of merchantable timber to be removed during each entry to the harvesting area or in terms of percentage of the standing merchantable volume to be removed. On the basis of a 30 year selective cutting cycle and Cambodian silviculture prescriptions under which only $30 \%$ of merchantable timber is removed (Decree 50), Sandan's harvest potential per hectare is $20.2 \mathrm{~m}^{3}$ (5.6 trees), $40.8 \mathrm{~m}^{3}$ (11.6 trees) and $54.3 \mathrm{~m}^{3}$ (12.7 trees) in poor, medium and rich evergreen forests, respectively (Table 8 ). The average harvest potential per hectare of all tree species for Sandan's evergreen forest is approximately $38.4 \mathrm{~m}^{3}$ (10.0 trees), of which $65.6 \%$ comes from dipterocarps.

\section{DISCUSSION AND CONCLUSION}

The analysis of the structure of the Sandan's evergreen forest shows wide variations in both stand density and stand volume (Table 5, 6 and 7). On average for stand density, $1,105.5$ trees $\left(235.2 \mathrm{~m}^{3} /\right.$ ha) were recorded ; of which dipterocarps represented $17.3 \%$. After the dipterocarps, other major species were Myrtaceae (12.5\%), Ebenaceae (7.9\%) and Euphorbiceae (4.4\%).

The structure of poor evergreen forest is not much different from those of medium and rich evergreen forests. The difference is in quantity; as poor evergreen forest has been repeatedly logged over recent years. Poor evergreen forest should be designated as forest reserve for at least 30 years. Firewood, however, should be allowed to be extracted because about $100 \%$ of Cambodia's villagers depend mainly on firewood for cooking energy.

On a selective cutting cycle of 30 years, the harvest potential of medium and rich evergreen forests theoretically varies from $40.8 \mathrm{~m}^{3} /$ ha to $54.3 \mathrm{~m}^{3} /$ ha. However, due to the fact that there is no information on the growth rate of Sandan's evergreen forests and a number of unknown trees are not commercial species, the annual allowable cut (ACC) should be set at $40 \mathrm{~m}^{3} /$ ha (based on assumption of growth rate of $0.56 \%$ of total stand volume). This figure is more or less the same as in Malaysia and Thailand. Forests in Vietnam were widely destroyed during the Vietnam War; thus their ACC must be less than that of evergreen forest in Cambodia.

The most likely species to be harvested are CHBG, PHDK and CRMS. Since unknown trees still represent a big proportion of the forest, any further study on such trees should be encouraged. The Cambodian government is still short of funds and human resources to reforest and properly manage the forests, and only logging companies have such resources. Thus, a selecting felling and replanting system as implemented in Indonesia should be introduced to Cambodia.

Forest management can no longer be concerned solely 
with timber production. The values of non-wood forest products are frequently overlooked, yet locally they may be much more important than wood products, and their production may be the key to involving people in participatory forest management. Non-wood forest products should be an integral part of the survival and development strategy for the continuing well-being of man, livestock and native flora and fauna (WICKENS, 1994).

\section{ACKNOWLEDGEMENT}

Authors would like to thank Mr. Pushparajah, FAO forestry advisor to Cambodia, for his valuable comments and documents. Mr. Vong Sarun and Mr. So Thea of department of forestry and wildlife, Cambodia are acknowledged for guiding the first named author to the field.

\section{LITERATURE CITED}

Choong, E.T. and Achmad, S.S., (1996): Utilization potential of the dipterocarp timbers of Southeast Asia (in Schulte, A. and Schone, D., (ed.), : Dipterocarp forest ecosystems-towards sustainable management). World Scientific, Singapore-New Jersey-London-Hong Kong, 481-524

Decree No. 50 (1986): Tree species classification and diameter limits for harvest. Government of Cambodia, Phnom Penh:1-4 (in Khmer)

DFW, (1998a): Report on establishment of a forest resources inventory process in Cambodia. field document No. 10, Project CMB/95/ 002, Phnom Penh, 80pp

DFW, (1998b): Forest cover statistics in Cambodia. DFW, Phnom Penh, 172pp

FAO, (1994): Readings in sustainable forest management. FAO forestry paper 122

FAO and UNEP, (1981): Tropical forest resources assessment project (in the framework of GEMS). Forest resources of tropical Asia.
Technical report 3 , FAO, Rome, 475pp

ITTO, (1994): The economic case for natural forest management PCV

(VI) $/ 13$. Volume II, country reports: Thailand 1-41, Malaysia 1-71 and Indonesia 1-27

Kim Phat, N., Uozumi, Y., OuK, S. and Ueki, T., (1999): Forest management problems in Cambodia - a case study of forest management of F company- J. For. Plann. 5: 65-71.

Maury-Lechon, G. and Curtet, L., (1998): Biogeography and evolutionary systematics of Dipterocarpaceae (in Appanah, S. and Turnbull, M. J., (ed.): A review of Dipterocarps-taxonomy, ecology and silviculture-). CIFOR, Jakarta, 5-44

Sist, P. and SARIDAN, A., (1998): Description of the primary lowland forest of Berau (in BerTaulT, J-G. and KAdiR, K., (ed.) : Silvicultural research in a lowland mixed dipterocarp forest of east Kalimantan). CIRAD-forest, FORDA and P.T. Inhutanii, Montpellier, 51-73

SutThisRisinn, C., (1999): Transition from reliance on domestic timber to dependency on imports. Proceedings of International symposium on global concerns for forest resource utilization-sustainable use and management. Japan Society of Forest Planning Press, Tokyo, 335-349

VAN, N. T., (1998): Forest resources utilization in Vietnam-transition from natural forests to plantation. Proceedings of International symposium on global concerns for forest resource utilization-sustainable use and management. Japan Society of Forest Planning Press, Tokyo, 362-368

Weidelt, H.J., (1996): Sustainable management of dipterocarp forests -opportunities and constraints (in Schulte, A. and Schone, D. (ed.): Dipterocarp forest ecosystems-towards sustainable management-). World Scientific, Singapore-New Jersey-London-Hong Kong, 249-273

Wickens, G.E., (1994): Sustainable management for non-wood forest products in tropics and subtropics (in FAO, (ed.) : Readings in sustainable forest management). FAO forestry paper 122, Rome

WORLD RESOURCE INSTITUTE (1989): Tropical forest species richness. World Resources Institute, ashington, 1-3

(Received 28 December 1999) (Accepted 16 June 2000) 